\title{
The making of successful public space: a case study of People's Park Square
}

\author{
C. K. Heng and V. Chan ${ }^{*}$ \\ School of Architecture, National University of Singapore, 4 Architecture Drive, Singapore 117566
}

People's Park Square is a lively urban node located in the heart of the historic Chinatown district in Singapore. It is well used throughout the week and is the focus of much of the pedestrian activity that goes on in the area.

This case study is part of an on-going research project on the nature of good Southeast Asian streets and urban spaces and through it, we hope to identify and document answers to such questions as: why is the Square a successful urban space? What are the factors that make it work? What are the designable physical characteristics of such spaces? What can be done to promote good streets and urban spaces?

For while the importance of creating good streets and urban spaces that provide conducive settings for public life is increasingly being acknowledged, the study of our regional urban environment has been, to date, largely neglected. Ultimately, the purpose of the study is to analyse the various factors involved in the makeup of successful Southeast Asian urban areas and to distill the findings into a set of physical designable characteristics that can be used to facilitate the future creation of successful urban spaces adapted to our regional requirements.

Keywords: urban streets and spaces; physical designable characteristics; Southeast Asia; pedestrian activity; public life

\section{Introduction}

\section{Objectives and methodology}

This case study of People's Park Square is part of an on-going research project on the nature of good Southeast Asian streets and urban spaces. The project was initially conceived as a result of the growing concern for the future of Southeast Asian cityscapes in the face of globalisation and the subsequent replacement of traditional neighbourhoods and indigenous urban fabrics with faceless modern ones. While the importance of creating good streets and urban spaces that provide conducive settings for public life and a greater civic consciousness is increasingly being acknowledged, the study of our regional urban environment has been, to date, largely neglected.

*Correspondence: C.K. Heng ${ }^{*}$, School of Architecture, National University of Singapore, 4 Architecture Drive, Singapore 117566
Through a series of empirical studies, the research aims to:

1. establish the criteria for good streets and urban spaces in our region;

2. identify the physical designable qualities of good streets and urban spaces; and,

3. compile a report that can be easily accessed by academics and designers in the region.

Ultimately, the purpose of the study is: to improve the understanding of urban streets and spaces relative to the Southeast Asian context; to analyse the various factors involved in the makeup of successful Southeast Asian urban areas; and, to distill the findings into a set of physical designable characteristics that can be used to facilitate the future creation of successful urban spaces adapted to our regional requirements.

The research team is currently undertaking a series of case studies in Singapore, Malaysia, 
Table 1 Physical dimensions as criteria by which to study urban streets and spaces

\begin{tabular}{|c|c|c|}
\hline \multicolumn{3}{|l|}{ Physical dimensions } \\
\hline Volume & Massing and enclosure & $\begin{array}{l}\text { Public space (open) } \\
\text { Public space (covered) } \\
\text { Semi-public space (enclosed) } \\
\text { Line of enclosure }\end{array}$ \\
\hline & \multicolumn{2}{|l|}{$\begin{array}{l}\text { Dimensions } \\
\text { Shape and configuration }\end{array}$} \\
\hline Ground plane & \multicolumn{2}{|l|}{$\begin{array}{l}\text { Level changes } \\
\text { Sub-division of space } \\
\text { Finishes }\end{array}$} \\
\hline Overhead plane & \multicolumn{2}{|c|}{$\begin{array}{l}\text { Definition of ceiling plane } \\
\text { Relationship of overhead plane to ground/vertical plane }\end{array}$} \\
\hline Vertical plane & \multicolumn{2}{|l|}{$\begin{array}{l}\text { Building frontages } \\
\text { Walls and facades }\end{array}$} \\
\hline Permeability & \multicolumn{2}{|l|}{$\begin{array}{l}\text { Physical } \\
\text { Visual }\end{array}$} \\
\hline Level of complexity and detail & \multicolumn{2}{|c|}{$\begin{array}{l}\text { Variety in sizes of elements } \\
\text { Variety in detailing and material }\end{array}$} \\
\hline
\end{tabular}

Thailand and the Philippines. Ultimately, by means of the case study approach, we hope to identify and document answers to such questions as: what are good Southeast Asian streets and urban spaces and what are the factors that make them work? What are the designable physical characteristics of such streets and urban spaces? What can be done to promote good streets and urban spaces?

\section{Western precedents and criteria}

Extant scholarship on the public realm, while primarily focused on discussions of Western prototypes and contexts, provides a good base from which to analyse, compare and contrast the possible criteria by which to study streets and urban spaces within the regional context. A broad review of existing texts was undertaken and what follows is a distillation of the manifold factors taken into consideration by various researchers (Tables 1-4).

\section{Historical background of Chinatown area}

The physical development of Chinatown began around 1843 when land parcels were released for

Table 2 Microclimate as criteria by which to study urban streets and spaces

\begin{tabular}{ll}
\hline Microclimate & \\
\hline Sun & Solar studies \\
& Glare \\
& Natural lighting \\
& Wind path \\
Wind & Airflow/airchanges \\
& Natural ventilation \\
& Mechanical ventilation \\
& Spill-over cooling for air-conditioned spaces \\
& Shade \\
Trees & Evaporative cooling \\
Water & Awnings \\
Specialised shading elements & Umbrellas \\
& Screens \\
Sound & Noise levels \\
Smell & Auditory stimulation levels \\
\hline
\end{tabular}


Table 3 Amenities as criteria by which to study urban streets and spaces

\begin{tabular}{lll}
\hline Amenities & & \\
\hline Furnishing & Fixed & Seating \\
& & Tables \\
& & Telephones \\
& Automated cash machines etc. & \\
& Semi-fixed & Shop displays \\
& Stall-front glass cabinets \\
& Non-fixed & Dustbins \\
& & $\begin{array}{l}\text { Pushcarts, makeshift stalls } \\
\text { (cobbler stations etc.) }\end{array}$ \\
& & Seating \\
Food and beverage provisions & Tables \\
& Stall/vendor & \\
& Retail outlet & Kiosks \\
& & $\begin{array}{l}\text { Pushcarts } \\
\text { Servery counters } \\
\text { Dispensers }\end{array}$ \\
& & Height and width \\
Covered pedestrian facilities & Walkways & Continuity \\
& & Weather protection \\
\hline
\end{tabular}

the building of homes and shophouses. A myriad range of activities flourished in the area - among them were small businesses such as goldsmiths, textile shops, pawnshops, spice and meat trading, night markets and thieves' markets, Chinese theatres as well as places of worship for the various immigrants of diverse religions settled in the surrounding area (Tyers, 1993).

South Bridge Road was the main thoroughfare at the time, leading from the city to the harbour. The rapid expansion of the population base inland towards the Duxton area and Pearl's Hill was due to increasingly overcrowded living conditions in the central Chinatown area as well as to improvements introduced to the transportation system - first with the steam train in 1885 , then with the electric train in 1905 and the trolley bus in 1929.

In the 1960s, with the adoption of urban renewal as the champion of progress, many traditional buildings around Pearl's Hill and New Bridge Road were demolished and redeveloped as part

Table 4 Activities as criteria by which to study urban streets and spaces

\begin{tabular}{|c|c|c|}
\hline \multicolumn{3}{|l|}{ Activities } \\
\hline Circulation & \multicolumn{2}{|l|}{$\begin{array}{l}\text { Vehicular: primary, secondary, tertiary } \\
\text { Pedestrian: primary, secondary, tertiary } \\
\text { Main flows of traffic } \\
\text { Routes and connections } \\
\text { Main points of entry into the area }\end{array}$} \\
\hline Pedestrian use and activities & \multicolumn{2}{|c|}{$\begin{array}{l}\text { Dynamic-active: main and secondary routes, intensive nodes } \\
\text { Passive-static } \\
\text { Types of activities }\end{array}$} \\
\hline Uses/activities & Variety of different activities in each area & $\begin{array}{l}\text { Passive: standing, sitting, eating, } \\
\text { talking, sleeping } \\
\text { Active: walking }\end{array}$ \\
\hline \multirow[t]{2}{*}{ Land use } & Land use at district level & $\begin{array}{l}\text { Number of types } \\
\text { Mix of use }\end{array}$ \\
\hline & \multicolumn{2}{|c|}{$\begin{array}{l}\text { Tenant mix: retail, commercial, parking and services, institutional/public, food } \\
\text { and beverage, office }\end{array}$} \\
\hline Public/private nature of space/use & \multicolumn{2}{|l|}{ Boundaries of public access } \\
\hline
\end{tabular}


of the government's overall plan and drive towards modernisation.

\section{Historical background of People's Park}

People's Park can be defined as the area bounded by New Bridge Road, Park Road and Pearl's Hill. In the early 1900s, the park acted as a green retreat for Chinatown residents who lived and worked in overcrowded conditions nearby. The nightlife in the area was particularly vibrant - 'Action starts soon after sunset. A lot of people mill around: itinerant hawkers set up stalls in their usual prime locations, and people come to be entertained by storytellers, news tellers, acrobats and magicians' (Archives and Oral History Department, 1983).

People's Park Market was set up in 1922 by the Municipal Authority and was the scene of much commercial activity as well as entertainment. Goods sold included meat, vegetables, cooked food and small items, and storytelling and other various forms of street entertainment were conducted in the open space in front of the market.

Unfortunately, the market was burnt down on Christmas Eve of 1966. Most of the hawkers from the market were later resettled in People's Park Centre (which was completed in late 1968 on the site of the old market).

People's Park and Eu Tong Sen Street were the former sites of shophouses and two important theatrical halls - Heng Seng Peng, where Cantonese, Peking and Hokkien opera were performed, and Heng Wai Sun, where Cantonese opera was the mainstay - all of which were demolished to make way for People's Park Centre.

The square as we know it today is directly bounded by People's Park Complex, People's Park Centre, Ocean Group (OG) Building and the Majestic Theatre. (The Majestic Theatre, formerly known as Tien Yien Moh Toi, was originally built in 1927 by $\mathrm{Mr} \mathrm{Eu}$ Tong Sen as a theatre for cantonese opera. It was later converted to a cinema and renamed Queen's theatre and, subsequently, Majestic Theatre.) The Southern Hotel, located along Eu Tong Sen Road adjacent to the Majestic Theatre, opened for business in 1927 and was then the tallest building in Chinatown and, besides hotel rooms, also housed a variety of uses, including a tea-house cum opera performance area on the roof terrace, a restaurant and offices.

The planning and land use principles adopted in the new developments (People's Park Complex and People's Park Centre) emulated those of the traditional shophouse typology in that they incorporated residential units on the upper levels with commercial and business uses on the lower floors. This made it possible to resettle and retain most of the displaced population within the area whilst achieving higher residential densities along with more intensive commercial use.

People's Park Square was a significant milestone of architectural development in Singapore in the 1970s for a number of reasons. Firstly, it introduced the modern air-conditioned shopping centre prototype that had previously been unknown in the local scene but, perhaps more importantly, it grouped together around a pedestrain-oriented space a collection of buildings that was varied not just in age, but also in style, function, form and class.

\section{Design intentions and analysis}

People's Park Square is one of the most successful urban spaces in Singapore (see Figure 1 for plan). It has been acclaimed as 'a successful design' 'built for people' shortly after it was built and is still very successful today, attracting large numbers of users (Loo, 1982, p. 28). At almost any one time, one could find elderly people (both residents and non-residents of the immediate surroundings), office workers, shop-keepers, labourers (from nearby construction sites), vendors, cobblers, tourists, housewives, children and teenagers using the square in a variety of manners. While the crowd of users may fluctuate during the day and reach a peak during evening hours, there are always enough passersby during the rest of the day to lend the place an air of constant activity (Figure 2). Some may be there to shop or sightsee, others are happy just sitting around people-watching, chit-chatting, or simply waiting (Figure 3). With the intensity of pedestrian activities, it is little surprise that street vendors such as newspaper stands/stalls, cobblers and lottery ticket sellers attempt to make their living there. People's Park Square promises to be ever more successful when the subway station of the new North East line is open in 2002. 


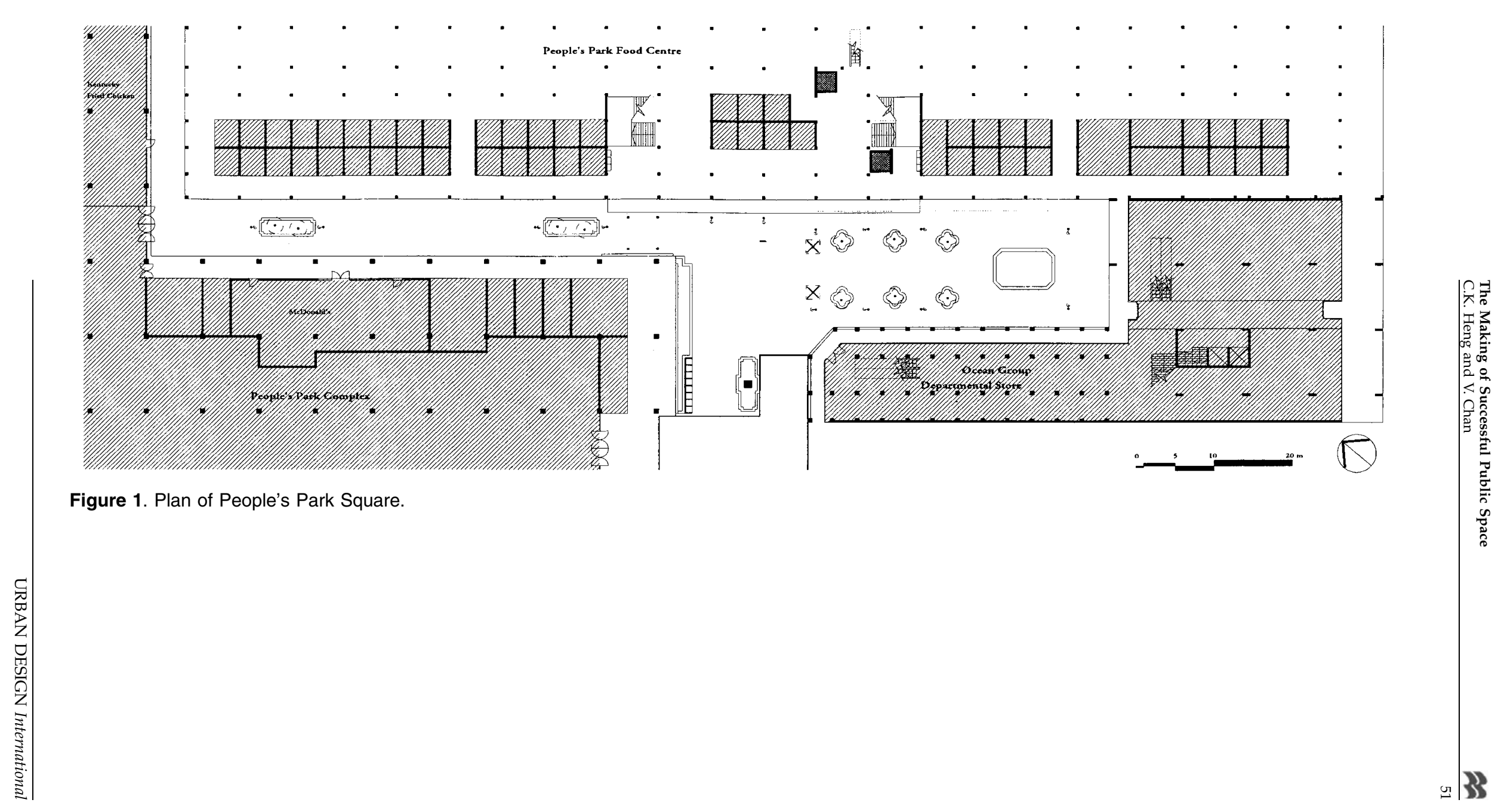




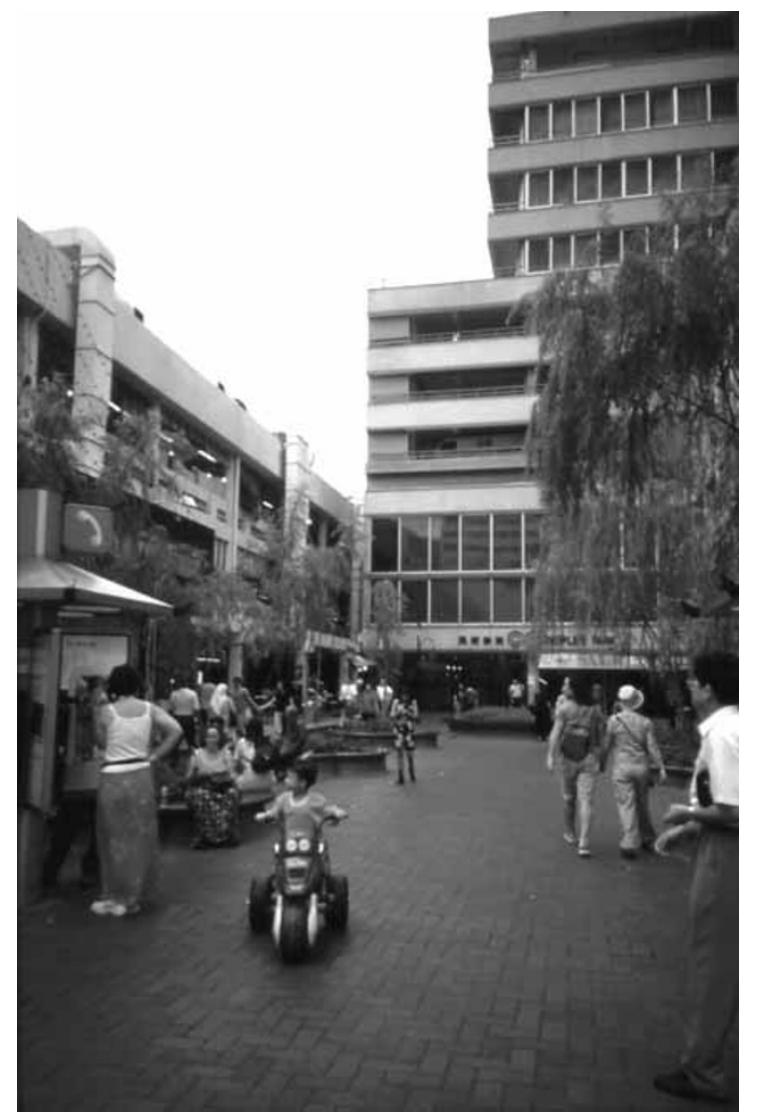

Figure 2. The bustle of various activities in the square throughout the day.
The success of the square was not an accident. The so-called square was initially a road that URA had 'block(ed) up ... and juxtaposition(ed) the buildings and put in some features, street furniture, plants, etc. to make it come alive' (Loo, 1982, p. 89). An earlier study shows that the square was planned, designed and anticipated to function the way it is currently functioning. The intentions and strategies were clearly articulated. 'The plaza (was) intended to group the buildings in a meaningful way ... we want(ed) to generate movement, complementary movement of people from one building to another and vice versa ... to identify which are the areas that people will walk along and make footpaths for them to walk along. Identify where people may want to sit, to rest and to have lunch and to talk.' The space, according to the designer, should not only be safe but also pleasant to walk and enjoyable so as to 'encourage more of the pedestrian to move ... through the space.' To the designer, 'a pedestrian mall is only able to succeed if you are able to link buildings together functionally, visually and to create a space ... frame the space and to make the space more meaningful' (Loo, 1982, p. 86). The space has to be flexible catering to various activities and 'must appeal to everybody'. It must not be differentiated 'that this area is exclusively for tourists and that for locals' or it 'will fail completely.' (Loo, 1982, p. 85).

Even at a larger scale, involving the area in

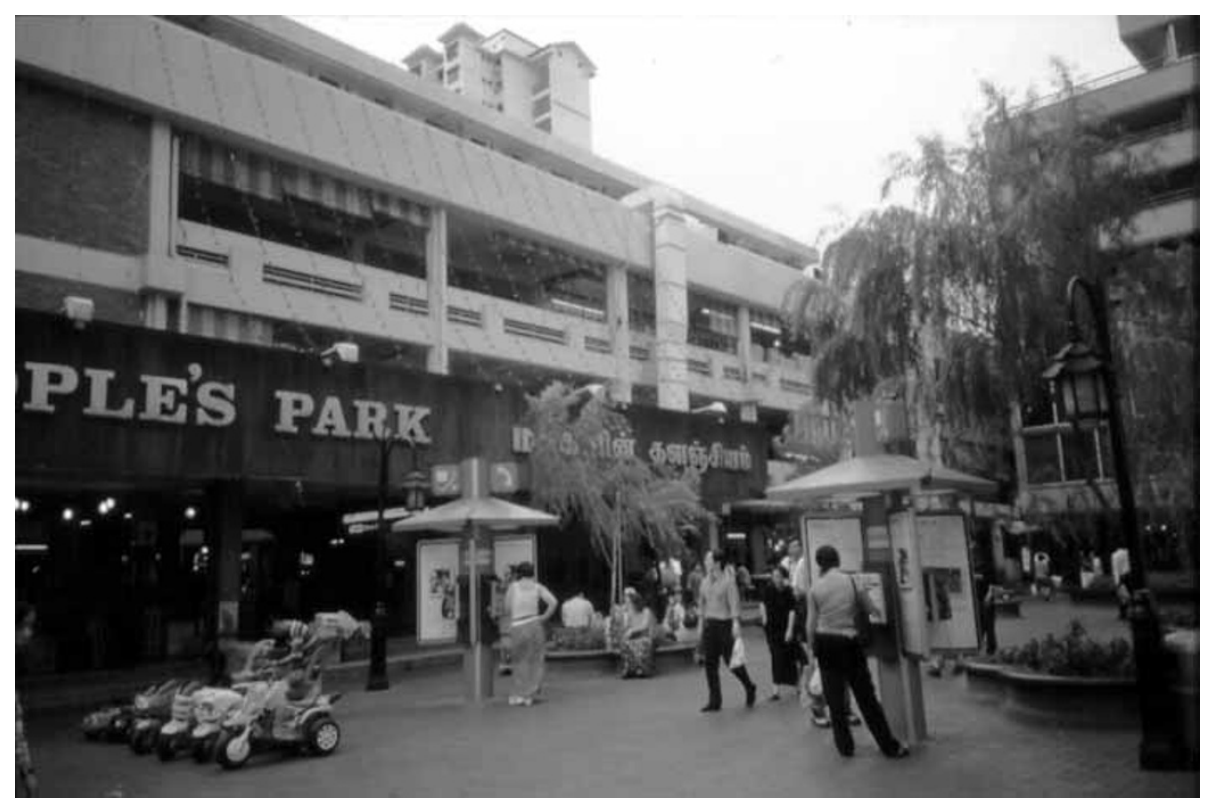

Figure 3. Users both passing through and lingering in the square. 
general, the objectives and strategies were equally clear. Adequate servicing and loading areas must be provided and fire-fighting and emergency vehicles allowed access even into the landscaped square. To make the square successful, 'you are to tell the people there to park their cars at the parking stations outside and not at the door.' Three car parks were built after some persuasion: at HDB's People's Park Centre, at People's Park Complex and at OG Departmental Store so that there are ' 3 major magnets almost surrounding the square to ensure that the people who drive there can park at any of the car parks there and walk through building to building' (Loo, 1982, p. 84). And all these were envisaged in a larger scheme which involves the creation of links across Upper Cross Street and a Major Main Open Square in front of Subordinate Court, Old Ministry of Labour Building and Furama Hotel.

The factors listed in the earlier section are certainly useful in helping us understand the success of the People's Park Square. Under the heading of amenities for instance, there are kiosks, seating, the clock tower, signage, planters, trees and flowers, a fountain (until recently) streetlighting etc. We have chosen, after extensive analysis however, to focus for the purpose of this paper on three important factors grouped under the heading of context and linkage system, interface and spatial system, climate and proportion. This is not to slight the importance of all the other factors which together are critical in ensuring a successful public space but to highlight certain critical factors that are specific to this urban space and its surroundings.

\section{Context and linkage system}

One of the reasons People's Park Square is able to function as well is its location, close to offices and residential and hotel areas. The good provision of public transport and parking facilities is also important. More important however is the fact that the square was planned in such a way that it not only linked up all the buildings at its edges but is also connected to other buildings and carparks beyond those immediately surrounding it (Figure 4).

Hence it taps on a much larger pedestrian network and becomes the confluence of several paths. Many people use the square as a pleasant short cut while others have to cut across the square to access a carpark or a nearby taxi stand.
Although the location of People's Park Square is an important factor, the deliberate creation of a context of linkages reinforces its strength and further enhances its success.

\section{Edge interface and spatial system}

Jan Gehl in his Life Between Buildings reiterates Christopher Alexander's comment regarding the importance of the edge: 'if the edge fails, then the space never becomes lively.' Indeed, the edges of People's Park Square deserve careful observation. All but one of its edges are permeable both visually and physically to various extends. Even then, the edge constituted by the blank wall of Majestic theatre did not always function as a blank wall. A niche in the wall provided, until the recent construction works, a popular fruit/fruit juice kiosk. Just as important along this wall was the side door of the cinema/theatre that at regular intervals during the day poured out a steady stream of moviegoers after each screening session. Adjacent to this edge is the glass vitrine of OG Department Store, perceptually permeable but only accessible through glass doors at specific locations. This edge, though not as active as the rest, however offers the opportunity for shoppers to rest on benches provided along it.

The other edges offer interesting lessons for the design of public spaces. While the buildings defining those edges are large in footprint and undeniably contemporary, the nature of the edges is less so. They are made up of narrow frontages along a walkway open to the square. These shop/ store fronts are mostly no wider than $5 \mathrm{~m}$ and offer a wide range of goods and services clearly visible and accessible along the walkway and from the public open space. The narrow shop fronts are able to give to the edges visual variety and to the passersby a wider range of goods offered and hence catering to different groups of people. The informal atmosphere created is also unintimidating to most people and therefore promotes more intensive use and patronage.

Equally important is the fact that these edges are only rather thin 'activity screens' linking the People's Park Square to the indoor spaces of the surrounding buildings. Designed with that intention in mind, the indoor city rooms (or atriums) of the People's Park Complex are linked almost seamlessly to the public space of the square. The same is true for the 'interior space' of the food centre and that of OG Departmental Store. In so 


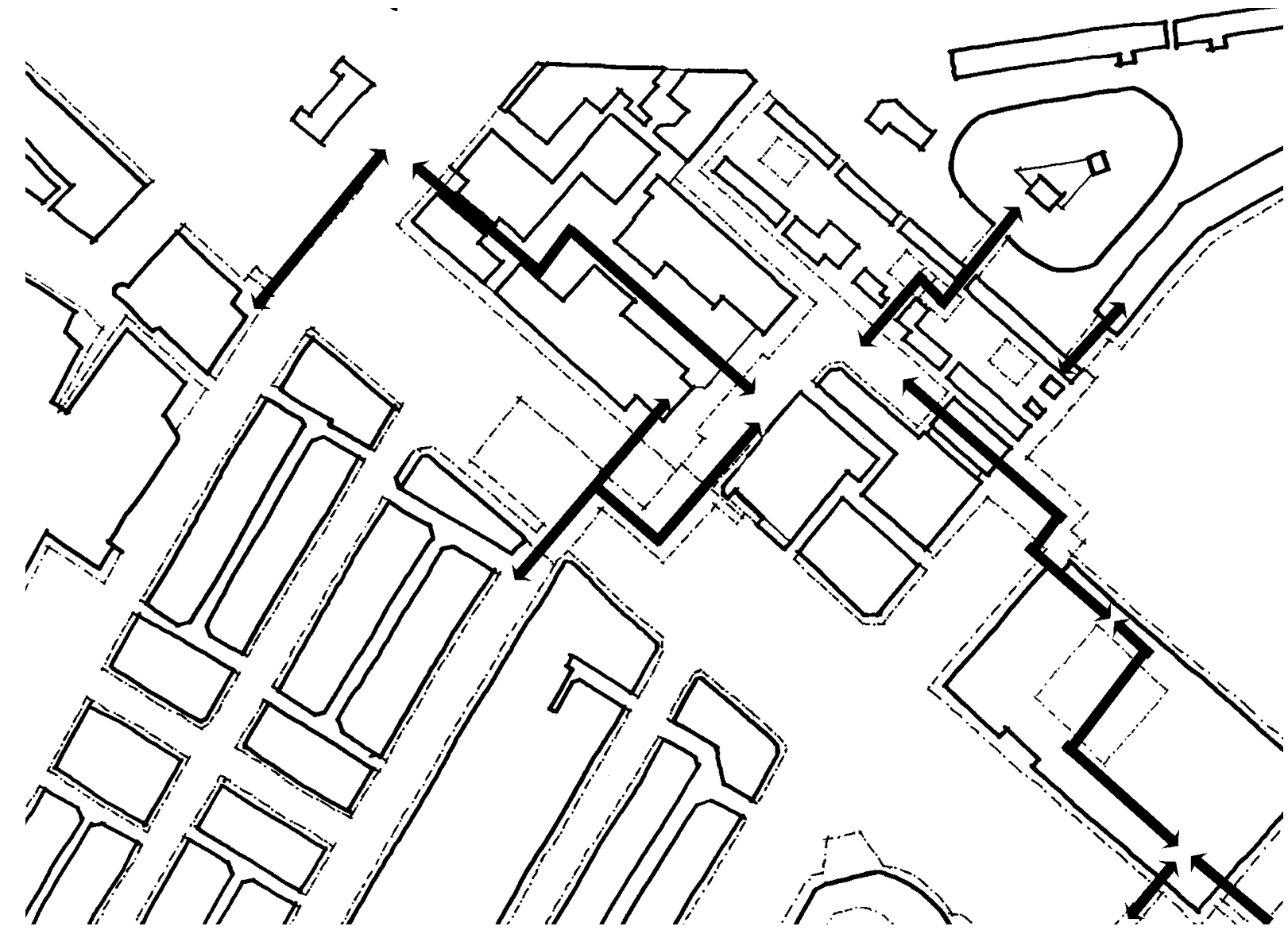

Figure 4. Context and linkage of the square to the surrounding district.

doing the outdoor open space of the square merges with the indoor space of the adjacent buildings to form a seamless spatial system that is connected not only visually but also by activities. This system is in turn linked via linear connectors, in the form of bridges, to buildings and carparks beyond its immediate perimeter (Figure 5).

\section{Climate and proportion}

A final point that merits some emphasis is the fact that this square was initially a road closed off because 'it serve(d) no useful purpose' (Loo, 1982, p. 83). Hence the proportion of this open space is long and narrow instead of large and ample, as most squares and plazas would be in the Western world. Despite this, or rather because of this, the People's Park Square is far more successful than it would have been otherwise. A comparison with some other squares in Singapore is revealing. The large Ngee Ann City Square or the outdoor open space in front of Tong Building both along Orchard Road, or the open plazas in front of commercial buildings both in the city centre and in the new towns are less successful during the day. This is especially so when there are few or no substantial trees to provide the much needed shade.

In the case of People's Park Square, the narrowness of the T-shape public space $(75 \mathrm{~m}$ by $20 \mathrm{~m}$ and $125 \mathrm{~m}$ by $20 \mathrm{~m}$ ) in conjunction with the taller buildings around it renders the square shaded most of the day. A daylighting study shows that at least $25 \%$ of the square is shaded $65 \%$ of the day (7am-7pm). Taking into account the shade provided by the trees, most of the square is shaded throughout the day. This is an important factor as the harsh tropical sun discourages any prolonged use of unshaded open space during the day. The fact that most of the square is shaded during the day also means that the square is cooler than other plazas in the evenings when the accumulated heat begins to radiate from the heated surfaces into the cooler surroundings.

This study of People's Park Square is only part of 


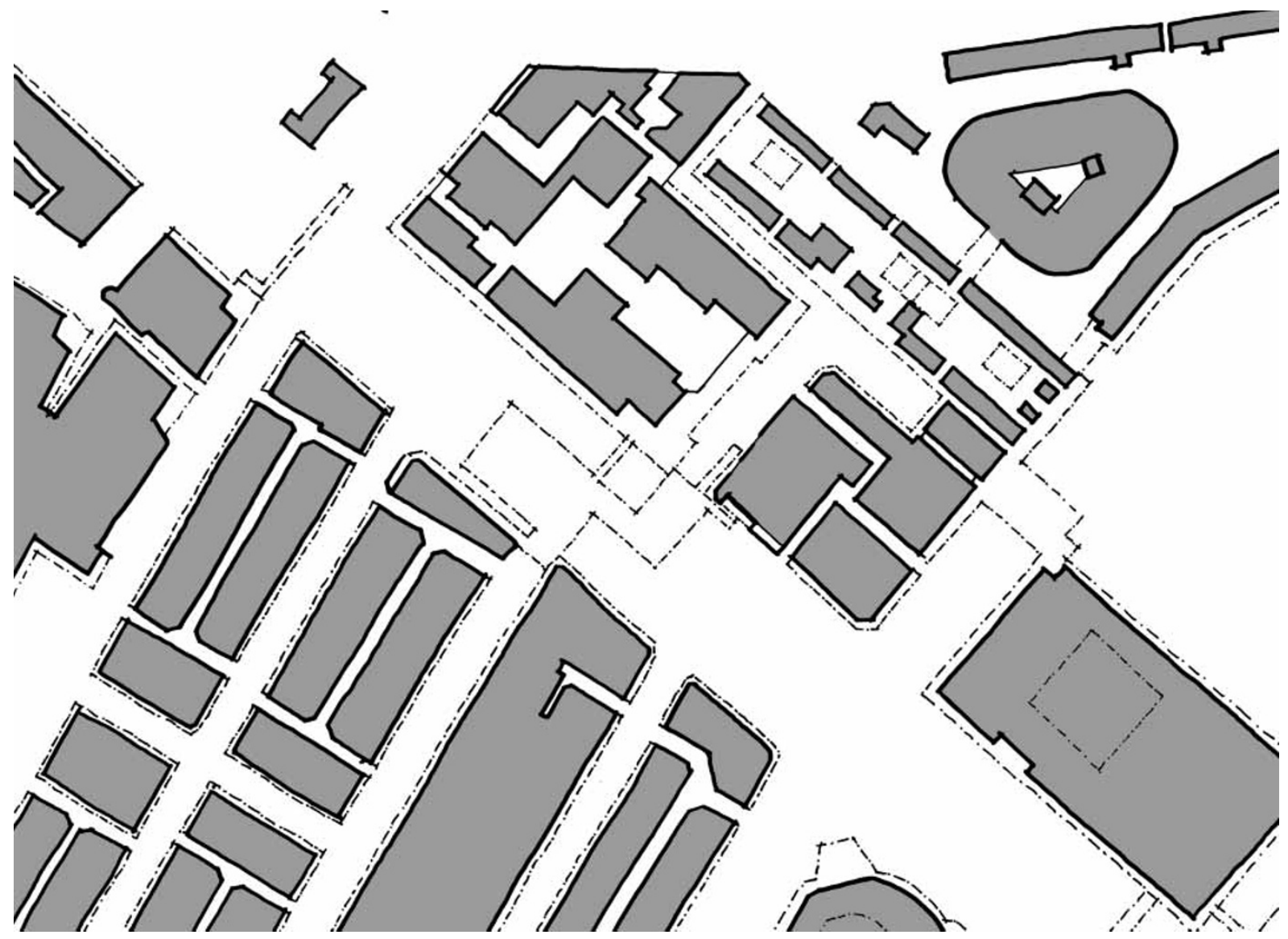

Figure 5. The square within the spatial system of the surrounding district.

our more extensive study on the nature of successful streets and public spaces in the region. Hopefully with the progress of the research in similar public spaces in our neighbouring countries, we could derive a better understanding of the factors behind the making of successful streets and urban spaces in our region.

\section{References}

Alexander, C. (1977) A Pattern Language: Towns, Buildings, Construction. Oxford University Press, New York.

Archives and Oral History Department (1983) Chinatown: An Album of a Singapore Community. Times Books International, Singapore.

Gehl, J. (1987) Life Between Buildings: Using Public Space. Van Nostrand Reinhold, New York.

Gehl, J. (1994) The Challenge of Making Human Quality in
The City. (Seminar held at the Faculty of Architecture and Building Estate Management, National University of Singapore.) Singapore.

Lang, J. (1994) Urban Design: The American Experience. Van Nostrand Reinhold, New York.

Loo, S.K. (1982) Evaluation of an outdoor urban space, People's Park Mall. (Unpublished dissertation for the School of Architecture, National University of Singapore.) Singapore.

Rapoport, A. (1977) Human Aspects of Urban Form: Towards a Man-Environment Approach to Urban Form and Design. Pergamon Press, Oxford.

Rapoport, A. (1987) Pedestrian Street Use: Culture and Perception. Van Nostrand Reinhold, New York.

Rapoport, A. (1990) History and Precedent in Environmental Design. Plenum Press, New York.

Rudofsky, B. (1969) Streets for People. Van Nostrand Reinhold, New York.

Tyres, R. (1993) Singapore Then and Now. Landmark Books, Singapore.

Whyte, W.H. (1980) The Social Life of Small Urban Spaces. Conservation Foundation, Washington, DC. 